Хомчак Р. Б. Бойко В. О. ${ }^{2}$ к.е.н., с.н.с.

1 - Міністерство оборони України, Київ;

2 - Центр воєнно-стратегічних досліджень Національного університету оборони України імені Івана Черняховського, Київ

\title{
Педагогічні аспекти психологічної підготовки військовослужбовців в сучасних умовах
}

\author{
Резюме. У статті викладено пропозиції щодо удосконалення психологічної підготовки \\ військовослужбовців Збройних Сил України. \\ Ключові слова: морально-психологічний стан, психолого-педагогічна підготовка, метод виховання.
}

Постановка проблеми та аналіз останніх досліджень і публікацій. Аналіз професійної діяльності офіцерського складу свідчить, що однією з головних іï складових $\mathrm{e}$ робота 3 людьми. Жодне бойове завдання не буде виконано без потрібного рівня психологічної підготовки особового складу до впливу відповідних психотравмуючих чинників. Сучасні високотехнологічні війни значно підвищують вимоги до особового складу, адже перемагає не зброя, а люди, що опанували нею на високому рівні, психологічно стійкі та підготовлені до дій в екстремальних умовах сучасного бою. Це вимагає від офіцера грунтовної психологічної підготовки, розвинених лідерських якостей i мотивів професійної діяльності. Від того, наскільки високим $\epsilon$ рівень психологічної підготовки офіцерського складу, значною мірою залежить успішність виконання поставлених перед військовиками завдань. Спроможність держави захищати свої інтереси формується у мирний час, хоча, на думку російських військових експертів, мирного часу в принципі не існує, війна у різних формах йде постійно, тільки протиборство стає більш чи менш інтенсивним, "гарячу" війну змінює "холодна", а психологічна, інформаційна, економічна війни не зупиняються ніколи [1]. Нестримний розвиток засобів і способів збройної боротьби, особливо за умов російсько-української гібридної війни [2], зростання ролі людського фактора в застосуванні бойової техніки та озброєння, обумовлюють ретельну підготовку особового складу збройних сил, потребують більш стійкого їх морально-психологічного стану.

Кардинальні зміни, що відбуваються сьогодні у всіх сферах нашого суспільства, процеси модернізації змісту й структури національної та військової освіти, реформування Збройних Сил України за умов проведення антитерористичної операції, коли війна ведеться не тільки за територію, але за прихильність населення, за уми людей методами інформаційнопсихологічної боротьби, значення моральнопсихологічних чинників стійкості військовослужбовців, зумовлюють підвищенню вимог до психолого-педагогічної підготовки офіцерського складу, що $є$ своєчасним та актуальним питанням сьогодення.

Аналіз останніх досліджень, публікацій показує, що новітні форми протистояння, на відміну до протистояння часів біполярного устрою, мають непевний, змішаний, хаотичний та множинний характер. Поєднання військових i невійськових способів ведення гібридного конфлікту, що застосовується у воєнних цілях та використовується як зброя вимагає удосконалювати психолого-педагогічної підготовку військовослужбовців Збройних Сил України. У працях А. Зикова, С. Смирнова, Н. Коупленда та ін. відмічено, як важко солдату, перш за все морально на полі бою, де масштабно використовуються танки, літаки та ін. зброя. Така картина бою характерна для періоду минулих війн. Сучасні війська повинні готуватись до конфліктів гібридного характеру, тому моральнопсихологічній складовій підготовки солдат i офіцерів повинно приділятись набагато більше уваги, адже ще Наполеон казав: “Духовна сила відноситься до фізичної, як три до однієї”, а Суворов підкреслював: "Не руки, не ноги, не людське тіло отримує перемогу, а безсмертна душа, яка править і руками, і ногами, і зброєю, - i якщо душа воїна велика і могутня, не піддається страху, і людина не падає духом на війні, то перемога безсумнівна, а тому потрібно виховувати і загартовувати серце воїна так, щоб воно не лякалося ніякої небезпеки і завжди було безстрашним".

Метою статті $\epsilon$ удосконалення психологічної підготовки військовослужбовців Збройних Сил України за досвідом АТО.

Виклад основного матеріалу. Вивчаючи досвід інших країн можна зробити висновок, що у будь-які часи проблема формування "духу воїна" 
розглядалась як основне завдання військовиків. Моральний стан військовослужбовців не можна побачити або сприйняти на дотик, але, як відомо, що це сама сильна зброя, більш могутня ніж бомба, танк або літак. Високий моральнопсихологічний стан військ - це засіб, який здатний перетворити поразку в перемогу. Армія не переможена доки іiі солдати не перейнялися свідомістю поразки, адже поразка це висновок розуму, а не фізичного стану.

У своїй книзі “Чому пала Франція” Андре Моруа пише: “Зараз можна сказати, що війна була програна Францією у той самий момент, коли вона почалась”. Одна лиш абсолютизація лінії Мажино, що виразилась у передачі всієї ініціативи супротивнику була вже поразкою, але ще більша небезпека була схована у інших факторах. Матеріальне забезпечення армії було дуже низьким: не вистачало сучасної зброї та спорядження. Керівництво роками вивчало суспільну думку замість того, щоб формувати іiі. Таким чином, питання життездатності нації руйнувалось, а не зміцнювалось. причини:

Падіння Франції обумовили наступні

- погане керівництво;

- низький моральний стан;

- відсутність ініціативи;

- недисциплінованість.

Закінчуючи 3 цим питанням, ознайомимося 3 деякими порадами, які дає Mopya:

Бути сильними. Якщо нація не готова вмерти за свою свободу, вона втратить їі.

Діяти швидко. Десять тисяч літаків, що побудовані своєчасно краще ніж п’ятдесят тисяч після битви.

Керувати суспільною думкою та формувати іiі.

Зберігати єдину країну. Політичні партії є пасажирами на борту одного корабля, якщо вони потоплять його, загинуть всі.

Вимагати від керівників вести чесне життя. Порок, який би він не був, завжди грає на стороні ворога.

Непохитно вірити в ідеї та обрис життя, за яке готовий віддати життя.

Зупинимося на іншому прикладі того часу, що, на нашу думку, гарно ілюструє поради Моруа. Це “Зимова” війна між Радянським Союзом та Фінляндією. Успішну оборону фінів, на відміну від французів, можна пояснити високим бойовим духом, який так і назвали “дух Зимової війни” під яким розуміють однодумність та готовність принести себе у жертву заради захисту Батьківщини. Дослідження підтверджують факти, згідно 3 якими, в Фінляндії вже напередодні Зимовій війни переважав консенсус відповідно того, що державу необхідно захищати у випадку агресії.
“Духом Зимової війни” перейнялися майже всі, навіть комуністи [3]. Незважаючи на великі втрати, Фінській армії завдяки високому морально-психологічному стану вдалося зупинити ворога по всім напрямкам. Аналіз подій показав, що коли боротьба приймає затяжний характер, результат їі вирішує моральна, а не фізична сила.

Перелічені приклади свідчать про те, що морально-психологічний стан військ - це питання життя чи смерті. Кожна добре організована армія зацікавлена в підвищенні рівня бойової підготовки, в забезпеченні сучасною зброєю, матеріально-технічними перевагами над супротивником. Однак матеріальні переваги не настільки важливі, як моральні. Для сучасної армії більш небезпечним $є$ ii низький моральнопсихологічний стан чим застаріла зброя.

$$
\text { Характерною ознакою “гібридних" }
$$
збройних конфліктів є збільшення у досягненні цілей конфлікту питомої ваги інформаційнопсихологічного впливу на особовий склад військ (сил), з метою дезорієнтувати його в обстановці, знизити здатність до опору, викликати непокору командирам та бажання до дезертирства.

Так, серед особового складу ЗС України у порівнянні з війнами інших періодів в ході АТО значно зросли психогенні втрати [4].

При цьому, результати аналізу воєнних конфліктів XX-XXI століть визначають наступну закономірність збільшення психогенних втрат особового складу та зменшення рівня стійкості військ за втратами, що вказує на збільшення залежності бойові спроможності військ (сил) від психологічної готовності особового складу.

Вимоги часу показали, що командир підрозділу є головним “джерелом” підвищення морально-психологічний стану. Виховна робота пов'язана 3 поведінкою офіцера i $€$ однією 3 найскладніших. Наслідуючи приклад офіцера, військовослужбовці тим самим розвивають свої професійно-значущі якості, формуючи i розвиваючи впевненість в своїй поведінці. Поперше, особистий приклад офіцера виступає умовою, що дає йому моральне право на виховання підлеглих. Слову начальника вони вірять, в тому випадку якщо воно не розходиться 3 ділом, підкріплено практикою, здатністю офіцера разом 3 військовослужбовцями долати тяготи військової служби, високим професіоналізмом. По-друге, особистий приклад офіцера є основою його авторитету. Про достоїнства i недоліки командира підлеглі судять по його справах i вчинкам. На підставі поведінки начальника, військовослужбовці формують про нього свою думку і визначають ставлення до нього. По-третє, особистий приклад офіцера представляє значну наочність.

Порівняння результатів оцінювання психологічної готовності особового складу у 
2015- 2016 роках в районах проведення АТО визначають збільшення довіри до безпосередніх командирів (начальників), покращання забезпеченістю озброєнням, військовою технікою, речовим, продовольчим забезпеченням та підвищення психологічної готовності до виконання завдань.

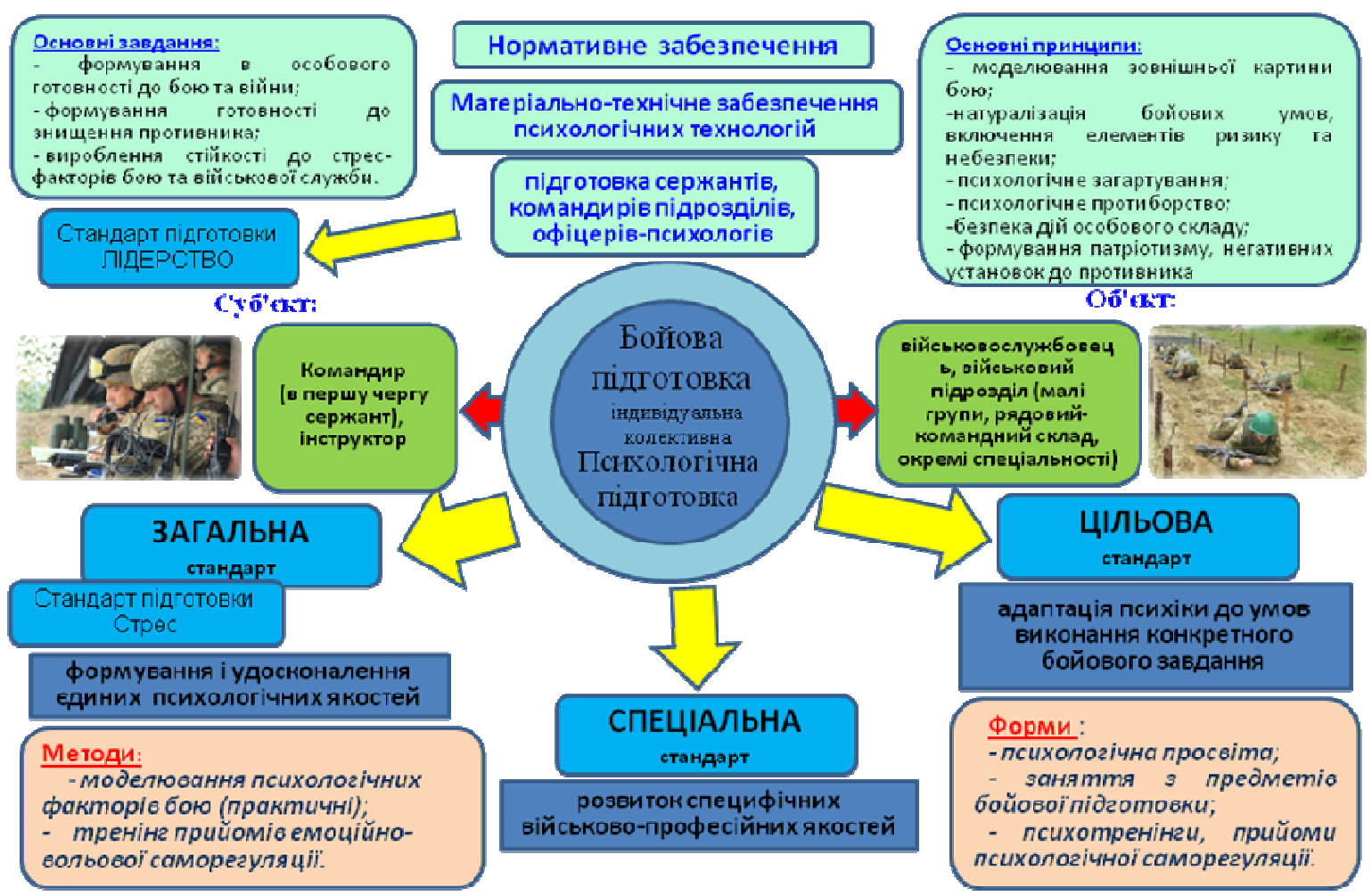

Рис. 1. Система психологічної підготовки

Психологічна підготовка у Збройних Силах України здійснюється у відповідності до вимог наказу начальника Генерального штабуГоловнокомандувача Збройних Сил України від 16.11.2012 № 240 "Про впровадження психологічної підготовки особового складу в навчальний процес підготовки органів управління та військ (сил)" 3 ycima категоріями військовослужбовців: в органах військового управління - під час проведення заходів оперативної підготовки (в ход $i$ навчань, тренувань); у військових частинах (підрозділах) - під час заходів бойової підготовки.

Система психологічної підготовки (рис. 1) повинна базуватися на основних положеннях i досягнення педагогіки i психології, на передовому досвіді роботи командирів усіх ступенів по вихованню військовослужбовців.

педагогічних аспектів підготовки військовослужбовців, пропонуємо починати з визначення ієрархії психологічних якостей офіцера як приклад для наслідування головні серед яких займають: організованість, відповідальність, наполегливість, гідність, працездатність. Звичайно, військовослужбовці хотіли б бачити перелічені риси в офіцері, тобто підлеглі бачать в офіцері більше командира, ніж педагога. Разом з тим офіцери вважають, що зразок для наслідування в їхньому уявленні повинен поєднувати впевненість в собі, чесність, доброзичливість, повага до людей, вміння слухати і вислуховувати, пунктуальність, що в більшій мірі характеризує його як педагога, а не командира. Таким чином, дане протиріччя вирішується в процесі службової і бойової діяльності і може служити педагогічною умовою психологічного виховання військовослужбовців.

Одним із важливих показників інтегральної якості психологічної готовності і стійкості воїна до впливу стрес-факторів сучасного бою $є$ рівень психологічної підготовленості військовослужбовця при виконанні нормативів і спеціальних вправ. Виходячи 3 такого підходу, достовірний висновок про психологічну підготовленість військовослужбовців до діяльності в бойових умовах, у ситуаціях небезпеки можна зробити тільки за наслідками оцінки їх діяльності, що здійснюється ними при моделюванні різних чинники (рис.2.). 


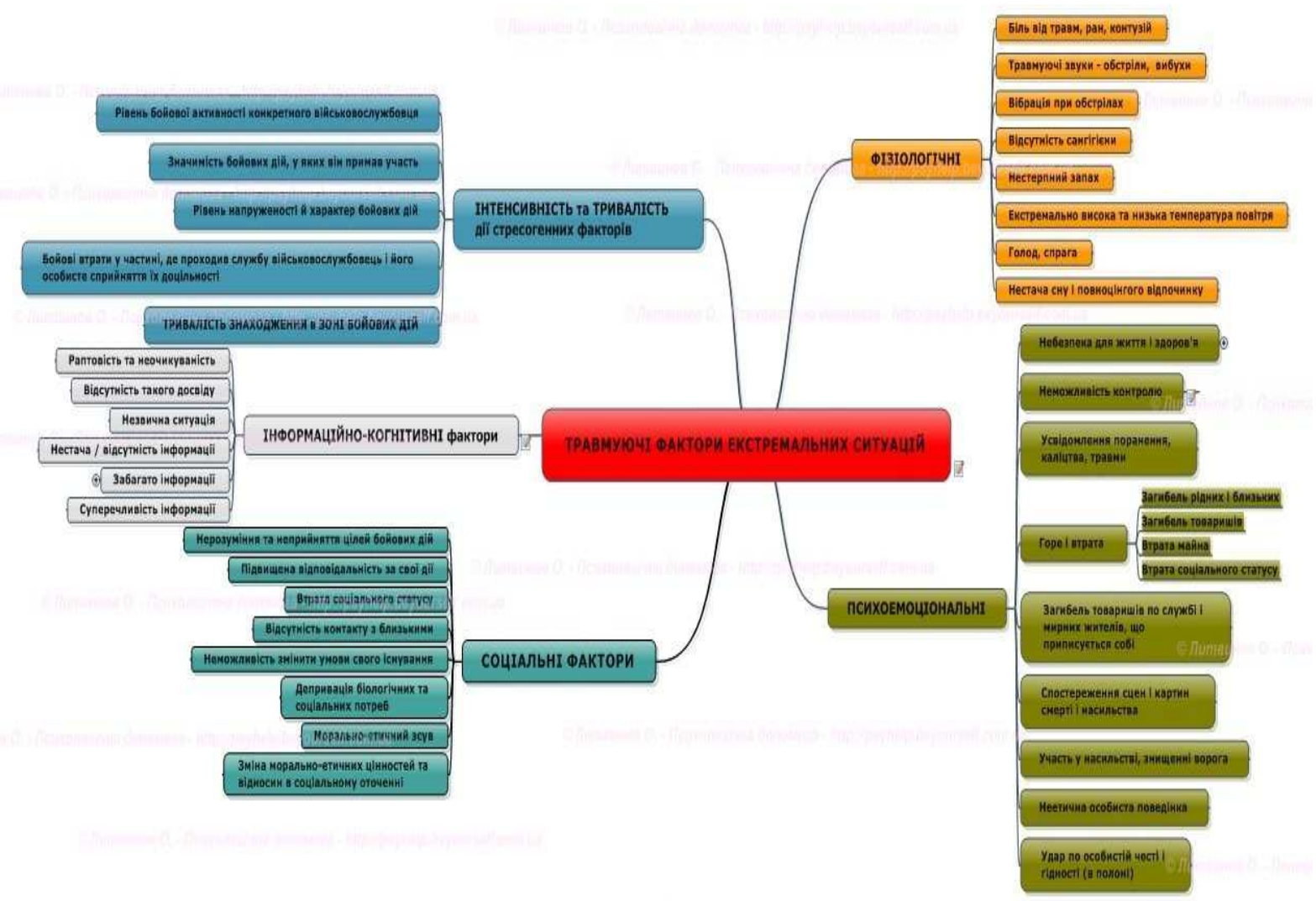

Рис. 2. Структура чинників, які впливають на формування психологічної готовності військовослужбовців

Оцінювання початкового рівня психологічної готовності і стійкості до ведення бойових дій необхідне для підготовки початкових даних. Вони, у свою чергу, потрібні для визначення дозування рівня психічних навантажень особового складу в процесі занять із бойової та гуманітарної підготовки.

Поняття психологічної готовності і стійкості включає безліч компонентів. Їх послідовна діагностика можлива, але дуже витратна за часом і посильна тільки фахівцю-психологу з високим рівнем підготовки. Однак ефективність ії оцінювання досягається формуванням експертної групи, які повинні мати базову психолого-педагогічну підготовленість. Окрім цього, нам необхідно знати не тільки індивідуальний рівень психологічної готовності і стійкості, але й рівень готовності підрозділу, а це не просто сума індивідуальних показників. Тому для визначення початкового рівня психологічної готовності і стійкості як індивідуальної (кожного військовослужбовця), так і підрозділу, пропонується застосовувати інтегральний показник, який може слугувати індикатором властивості, що діагностується, зважаючи на результати діяльності військовослужбовців, при виконанні будь-яких нормативів навчально-бойової діяльності в умовах моделювання впливу психологічних чинників бою на їхню психіку.

Під час психологічної підготовки підлеглих командирам підрозділів важливо зосередитися на актуалізації бойових мотивів, роз'ясненні цілей і необхідності майбутніх бойових дій. Чим більше бойові дії будуть наповнені для військовослужбовця особистісним сенсом, цінністю для себе, поняттям значущості своєї особистої ролі, почуттям справедливості своїх дій, упевненістю в собі і своїх товаришах, тим більше буде стійка його психіка до впливу різних стрес-чинників бойової обстановки. Важливо пам'ятати, що під час очікування бойових дій особовий склад має бути постійно зайнятий справою і максимально поінформований. За відсутності корисної діяльності та інформації виникають томливі роздуми, розмови, виникають різні чутки, зароджується страх перед невідомістю, настає загальний занепад бойового духу. Порушення психічної рівноваги не лише завдає шкоди здоров'ю людей, знижує їх боєздатність, але часто вимагає значного часу.

Для оцінювання психологічної підготовленості військовослужбовців під час навчально-бойової діяльності можна взяти показники із виконання контрольних завдань [5]. Отримані результати кожного військовослужбовця окремо і колективу в цілому зіставляються у різних ступенях наближення до умов бою за психологічним змістом. Необхідність порівняння 3 діяльністю в нормальних умовах пояснюється можливістю віднесення помилок, що виникають через відсутність відповідних знань і навичок. Контрольні завдання складаються спеціально для кожного контингенту військовослужбовців (за видами і родами військ) з урахуванням завдань, що вирішуються ними в 
бойовій обстановці. Контрольні завдання повинні: відповідати вимогам керівних документів і програм бойової підготовки; зважати на специфіку професійної діяльності обстежуваних військовослужбовців і відповідати потрібному рівню підготовленості; ураховувати особливості різних видів бою (наступ, оборона, марш, зустрічний бій тощо); охоплювати (за можливістю) всі об’ єктивно вірогідні варіанти бойових ситуацій.

Висновки. Дослідження показують, що майже $80 \%$ військовослужбовців вважають безпосереднього командира прикладом (зразком для наслідування), вбачаючи в ньому військового професіонала 3 активною життєвою позицією, і військового педагога. Сприймаючи різноманітні зразки поведінки оточуючих людей у військовослужбовця виникає потреба в поліпшенні власних особистісних якостей, такий психологічний механізм впливу наслідування. Тільки вчинки і дії офіцера, на відміну від його слів, можуть дати чітке уявлення підлеглим про правила поведінки. Військовослужбовці постійно спостерігають, як офіцер тримає себе при виконанні повсякденної службової діяльності, як він одягнений, як ставиться і як поводиться з підлеглими. Інтерес підлеглих викликає і ставлення офіцера до своїх обов'язків, як реагує на різні події. Особливу цінність в офіцера представляє вимогливість, наполегливість, завзятість, цілісність характеру.

Основним критерієм правильності дій є виконання поставленого завдання, збереження життя $\mathrm{i}$ здоров’я людей, збереження зброї і матеріальних цінностей.

\section{СПИСОК ВИКОРИСТАНОЇ ЛІТЕРАТУРИ}

1. Синявская Е. Психология войны в XX веке - исторический опыт России /[Електронний ресурс]. - Режим доступу: http//fb2.booksgid.com/content59/eiena-senyavskaya-psihologiya-voyny-v-xx-veke/137.html

2. Світова гібридна війна: український фронт./ монографія за ред. В. П. Горбуліна. - К.: НІСД, 2017. - 496 с.

3. Зимняя война глазами финнов. /[Електронний pecypc]. - Режим доступу: http//finland.fi/ru/zhizn-iobshhestvo/zimnyaya-voina-glazami-finov/.

4. Актуальні проблеми психологічної допомоги, соціальної та медико-психологічної реабілітації учасників антитерористичної операції. / МатеріалиVI міжвідомчої науково-практичної конференції 26 травня 2016 року.

5. Військова педагогіка у професійній діяльності офіцера і сержанта : навчальний посібник. Книга 1. “Загальні основи педагогіки та військова дидактика" / [О.В.Бойко, Л. В. Коберський, В. М. Кожевніков, А. М. Романишин, С. В. Скрипник] - Львів : АСВ, 2012. - 454 с.

Стаття надійшла до редакції 04.07.2017

Хомчак Р. Б.

Бойко В. А. ${ }^{2}$ к.экон.н., с.н.с.

1 - Министерство обороны Украины, Киев;

2 - Центр военно-стратегических исследований Национального университета обороны Украины имени Ивана Черняховского, Киев

Педагогические аспекты психологической подготовки военнослужащих в современных условиях

Резюме. В статье изложены предложения по совершенствованию психологической подготовки военнослужащих Вооруженных Сил Украины.

Ключевые слова: морально-психологическое состояние, психолого-педагогическая подготовка, метод воспитания.

\section{R. Homchuk ${ }^{1}$;}

V. Boiko, Ph.D, senior researcher ${ }^{2}$

1 - Ministry of Defense of Ukraine, Kiev;

${ }^{2}$ - Center for Military and Strategic Studies of the National Defence University of Ukraine named after Ivan Chernyhovsky, Kyiv

\section{conditions \\ The pedagogical aspects of the psychological training of servicemen in modern}

Resume. The article outlines proposals for improving the psychological training of servicemen of the Armed Forces of Ukraine. education.

Keywords: moral and psychological condition, psychological and pedagogical preparation, method of 